\title{
Identification of plant diseases and distinct approaches for their management
}

\author{
Lovepreet Kaur ${ }^{1}$ and Shiwani Guleria Sharma ${ }^{2 *}$ (]
}

\begin{abstract}
Background: Globally in the agricultural industry the major loss faced by is due to plant diseases. Various pathogens are responsible for causing plant bacterial and viral diseases, the treatment of them is very important in order to bring out the best quality and quantity of the agricultural yield. Before Technology came into practice the plant disease were identified by visual examination, the main symptoms such as curling of leaves and change of colour were observed. With advancements in science the microscopic examination for more clarity regarding diseases came into existence.

Main body: The distinct methods involve use of nucleic acids and serological assays were implemented to study bacterial and viral characteristics of the infecting pathogen. Traditionally, seed coating and mulching techniques were more common among farmers to generate better quality of the crops and prevent plants from any disease but currently new innovative methods are used. Microbial bio control agents are now one of the widely used approach in which microbial species are used to eliminate or inhibit the growth of pathogens in order to reduce the severity of the infection. Similarly, like microbial agent's different chemicals are present in order to kill the pathogens. These chemicals are classified as bactericides, fungicides and nematicides which suppress the plant infection caused by bacteria, fungal and nematodes, respectively.

Conclusions: In the forthcoming years, the development of more innovative agricultural-related techniques is prime that will help in increase of the yield and provides resistance to plants. Some of them are developed earlier but there is still need to develop more pathogen-resistant species for example in case of silencing of genes with insertion of a viral segment.
\end{abstract}

Keywords: Plant diseases, Bio control agents, Pathogens, ELISA, FISH

\section{Background}

The major loss is faced by the agricultural industry is due to plant diseases. Various pathogens are responsible for causing plant bacterial and viral diseases, the treatment of them is very crucial. Earlier, on the basis of the natural phenomenon, it was assumed that evolution was the only process to deal with pathogens in which plants themselves undergoes the process of evolution either they develop resistance or sensitivity to the pathogens

\footnotetext{
*Correspondence: shiwani@pau.edu

${ }^{2}$ Department of Microbiology, College of Basic Sciences and Humanities,

Punjab Agricultural University, Ludhiana, Punjab, India

Full list of author information is available at the end of the article
}

attacked. However, with time and introduction of the new techniques things are now different and changed (Fang and Ramasamy 2015). The developments in science and technology implemented various new methodologies for the treatment of the plants. From the beginning of the 1765 new methodologies were adopted, when the identification of various cryptogrammic parasites was done. Earlier, the plant diseases were identified by visual examination of the various parts of the plants in which the curling of leaves, change of colour from red to yellow and spots either brown or white (Lopez et al. 2003). With scientific progression, the microscopic examination came to effect in order to observe and study various pathogens 
involved in cause of a disease (Belet Chane and Boyraz 2019).

\section{Main text}

Traditional approaches to plant disease management In 1929 H.H. Whetzel articulated the development of some basic principle that can be followed for the treatment of the plant diseases that are avoidance, exclusion, eradication, elimination and destruction. The main focus of these principles was on protection, resistance and therapy in which the use of toxicants was there in order to prevent infection (Spadaro and Gullino 2005). Despite of the advantages there are various shortcomings of these principles such as, they were failed to provide dynamics of the diseases depicting severity of it with time. Traditionally, farmers used to identify the disease by visual examination after that they used to follow some traditional methods (Fig. 1) for the plant treatment which are discussed as follows:

I. Seed treatment-In this method, the seeds were soaked in warm cow's milk for approximately several hours, than they were treated with cow's ghee and dung (Shanti et al. 2010).

II. Removal of ulcers and patches-Initially, a sharp knife is used to remove the ulcers from the affected plant than a paste is prepared with help of cow ghee and Embelia ribes (Chitarra and van den Bulk 2003).

III. Prevention from sun scorching-In order to prevent rusting of coffee leaves and blight of tea due to blis- ter shading of the plants was done (Bürling et al. 2011).

IV. Suppression of the soil-borne pathogens-Use of raised beds and ridges. For example, in Mexico for the treatment of the Pythium and Phytopthora which are soil-borne pathogens, the chinampas or floating garden were used (Bonaterra et al. 2007).

V. Suppression of the air and seed-borne diseasePlanting was done across the direction of the wind so that the airborne pathogens do not intervene with the plants (Garrett et al. 2010).

\section{Innovative approaches for the detection of plant diseases}

Presently, some basic molecular techniques are used for the detection of the various diseases. These molecular diseases are categorized under two approaches, i.e. serological assays and nucleic acid-based approaches. The serological assays are used to detect various bacterial and fungal pathogens, the techniques require monoclonal and polyclonal antibodies in order to detect pathogens (Singh et al. 2013). The approaches like restriction fragment length polymorphism (RFLP) and loop-mediated isothermal amplification can also be utilized for the detection purpose (Jones 2009). Additionally, different direct and indirect methods can be used such as western blot, polymerase chain reactions, immunofluorescence, fluorescence in situ hybridization, thermography, hyperspectral techniques, fluorescence imaging and biosensors (Barnes and Szabo 2007).

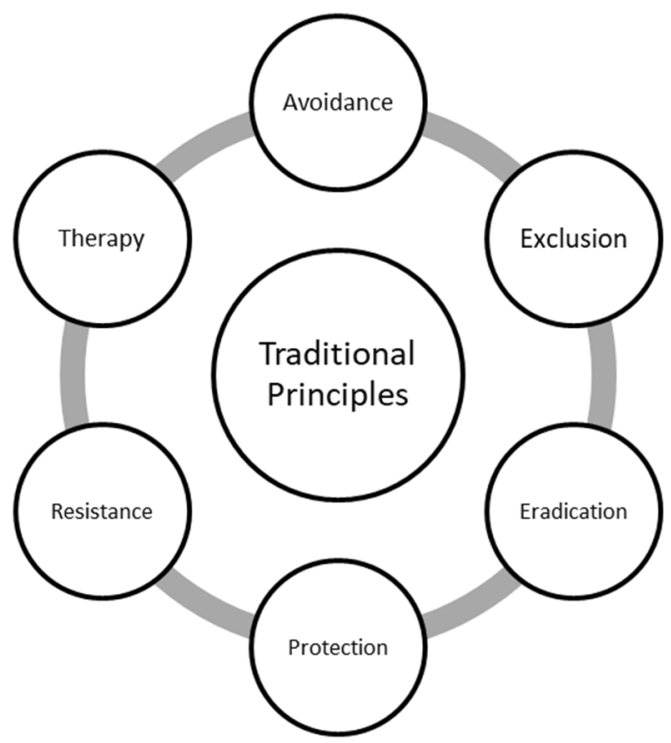

Traditional principles were adopted by the farmers in order to control the pathogen attack on the plants and to prevent any further spread of the disease. These methods allow selection of a particular time or seasonal which reduces resistance of a plant to a pathogen. These principles were finalised by the US National Academy of Science, each principle plays a significant role in prevention of the disease either by preventing the introduction of the inoculum or by eliminating or inactivating it.

Fig. 1 Traditional principles of pathogen attack control 


\section{Some of the molecular techniques are discussed as follows}

Presently, some basic molecular techniques are used for the detection of the various diseases. These molecular diseases are categorized under two approaches, i.e. serological assays and nucleic acid-based approaches. The serological assays are used to detect various bacterial and fungal pathogens, the techniques require monoclonal and polyclonal antibodies in order to detect pathogens (Singh and Singh 2013). The approaches like restriction fragment length polymorphism (RFLP) and loop-mediated isothermal amplification can also be utilized for the detection purpose (Jones 2009). Additionally, different direct and indirect methods can be used such as western blot, polymerase chain reactions, immunofluorescence, fluorescence in situ hybridization, thermography, hyperspectral techniques, fluorescence imaging and biosensors (Barnes and Szabo 2007).

Some of the molecular techniques are discussed as follows

I.Enzyme linked immune sorbet assay-This technique was introduced in 1970 and is effectively used for the detection of the viruses in plants. It has been used for the detection of the grapevine virus and to detect Xvlella fastidiosa which is a causative agent of the Pierce's disease. In this approach, the detection is based on antibody-antigen interaction, the reaction obtained from it is observed as a change in colour in the assay (Aslam et al. 2017). This change in colour in the assay depicts whether a reaction has occurred or not, i.e. how an antibody reacted towards antigen attached with a specific epitope on its surface. Specifically, an epitope is regarded as an antigenic determinant which is capable of eliciting an immune response.

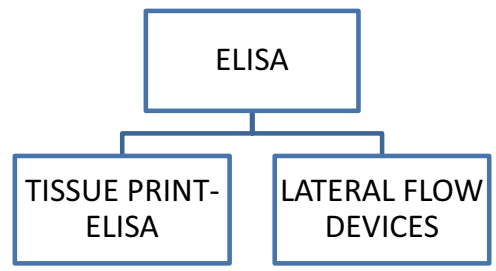

\section{APPROACHES FOR THE ON-SITE PLANT DISEASE DETECTION}

There are two different methods for the on-site detection of the plant diseases that are tissue-print ELISA and lateral flow device, but they cannot be used in case where no visual symptoms appear or in pre-symptomatic conditions.

- Lateral flow-The principle of lateral flow immunoassay is very simple; the extracted product which contains the analyte is run over different zone of the strip which is polymeric in nature (Gullino and Kuijpers 1994). During the process, the sample extracted from the plants part is applied on one side of the strip which is laid over the adsorbent sample pads. These pads are covered or layered with buffer salts which later on help in the easy detection of any kind of interaction that occurred between the particles (Nygren et al. 2018). Following it the conjugate pad contains the conjugated coloured fluorescent nanoparticles bound to the antibodies. The target analyte bind to its specific antibody and then the detection occurs at the detection zone of the lateral flow analysis strip (Lugtenberg et al. 2007).

- Tissue-print ELISA-it is also known as direct tissue blot immunoassay, i.e. DTBIA. It is widely used technique as it helps to identify the pathogen from its distributed location in a host cell. It does not require any prior preparation of the sample mixture (Torres 2010). The direct immune-printing enzyme linked immunosorbet assay can be carried out in three steps which involves, imprinting of the sample on the nitrocellulose membrane followed by addition of the CTV-specific antibodies and blocking with help of the alkaline phosphatase conjugate. At the end, the addition of the substrate is done in order to attain the final detection of the sample tested (Hijri 2009). Alkhalaf et al. (2009) demonstrated the immunoassay of direct tissue blot in which the detection of the bean yellow mosaic virus was done. In which the detection was done on lentils, peas and faba bean plants. The figure clearly represents the detection and identification of the bean yellow mosaic virus with help of the tissue immune blot assay (Alkhalaf et al. 2009).

II. Fluorescence in situ hybridization (FISH) - It is one of the most well-established approaches used for the detection of the bacteria and fungi in case of the plants. It works in combination with the microscopy as well as hybridization which helps in the extraction of the target genes from the plant samples with help of their DNA probes. Cytogenetic is involved in this technique in order to detect and locate specific DNA sequence present in the genome (Gaillet and Rouanet 2015). The probes used are labelled with haptene due to their specific binding characteristics as they only bind to the sequence which shows high percentage of the similarity (Fig. 2).

III. Western blots-A Plum pox virus was detected from Nicotiana benthamiana with the help of the 


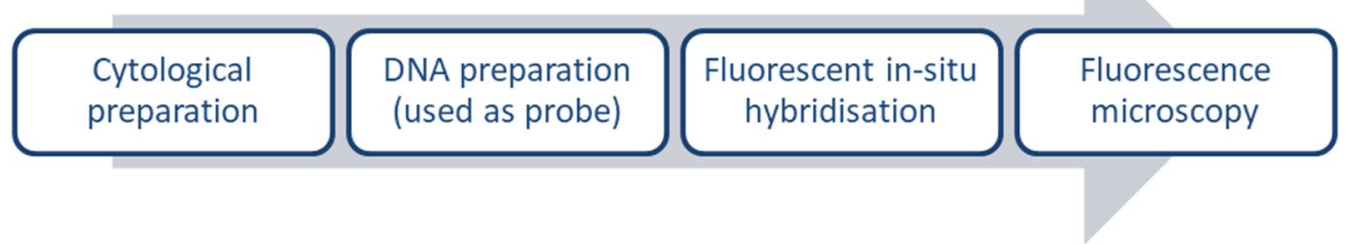

Fig. 2 Flow chart of steps involved in FISH

immune-blotting technique. In this process, different parts of plant were infected with the PPV capsid protein and after 21 days of the inoculation the Plumpox virus was detected. This method was effectively used for the detection of the plant virus characteristics and virus-particle protein interactions (Bashan and Holguin 1998).

IV. Nucleic acid-based techniques-Among various different techniques the polymerase chain reaction is used for the detection of the plant pathogens. In the processes, the one common approach used is enrichment of the pathogen in media selective before the final application of the molecular techniques (Spadaro and Gullino 2004). In case of PCR techniques the common targets are the ribosomal RNA genes and intervening sequences from the bacterial, fungal and nematode pathogens (Zhang et al. 2005). The nucleic acid techniques offer great advantages for the process of detection of distinct pathogens some of them are discussed as follows.

- For the detection of various obligate parasites which are present in a complex environmental conditions (Lievens et al. 2006).

- Detection of the organisms whose growth rate is too slow and the chances of the contamination are more (Nutter and Schultz 1995).

- They are widely used to identify the species that are morphologically similar to the non-pathogenic organisms (Mehta and Rosato 2001).

- Molecular detection of the pathogens having regulatory concerns can be detected with help of various nucleic acid-based techniques for example, Phytophthora ramorum, Xanthomonas citri and Tilletia indica (Martinelli et al. 2014).

- With the help of the nucleic acid techniques, the quantification of the pathogen biomass from the host cell can be done. Moreover, the geographic origin of the pathogens with historical origin can also be identified (Nutter and Schultz 1995; Mehta and Rosato 2001).
- Co-PCR can be used for the detection of the viruses and bacteria. In case of plants in a single reaction the detection can be done, thus this will reduce any chances of the contamination during the analysis of the pathogens. When a Co-PCR is coupled with a colorimetric technique of the detection then the sensitivity for the virus detection increases. Hence, making it easy for the highly unstable viruses to get detected in one go (Martinelli et al. 2014).

- Reduction of time and cost due to M-PCR approach. As in cases where multiple pathogens are responsible for the infection of a single plant with help of nested and multiple PCR technique. It will be easy to detect multiple causative agents at a single time (Koczula and Gallotta 2016).

\section{Pathogen control}

In order to meet the demand of the population, there is a need to control the plant diseases so as to maintain equilibrium between the quality and quantity of the food commodities. Various approaches are used for the control of the disease with help of some chemicals or by biological methods with help of microbes. Each method has their own mode of action for instance such as:

- Biological control agents-They supress the growth of the pathogen by inducing resistance to plants or by modulating the conditions required for the growth of a pathogen in the host body (Garnsey et al. 1993).

- Chemical control-The use of chemical pesticides and insecticides was abundant with their great positive effect rate. These chemicals result in causing environment and agricultural pollution so in order to preserve the environment various norms have been implemented by the government against such chemical pesticides. Consequently, now researchers are more focussed towards the development of the different microbial control agents in bulk against all plant species so as to control the plant infections 
with an alternative to chemical methods (Whipps 2001).

\section{Biological control agents}

As the name defines itself, i.e. microbial biological control agents means use of distinct microbes which includes nematode, bacteria, virus, live predatory insects etc. for the control of the plant infection. In study of the plant pathology, the supressing of the pathogens with microbial antagonists and use of host-specific pathogens for mitigate weed describes the term BCA, i.e. biological control agents (Beale and Pitt 1995). The extracts from the microbes can be fermented and used as BCAs, formulating such mixtures is very easy. Natural products are used and they provide multiple effects on the host and the pathogen.

- Mechanism of Action-Each microbial control agent has their own specific mechanism of action but some basic modes include mimicking the pathogens, reducing the nutrient content in host plant so that the growth of pathogen can be hindered (Weller 2007). Additionally, inducing resistance to plants, directly targeting the metabolic pathway of the pathogens and decreasing or increasing the temperature within the host plant are other modes used. The prime role of each BCA is to control the infection (Dun-chun and Lian-hui 2016) (Fig. 3).

- Interactions between plant and pathogens-Plants and pathogens undergo various interactions either specific or non-specific in nature throughout their life cycle. Some interactions benefit both pathogen and its host while other benefit one either host or pathogen and some do not benefit either. Different types of interactions are mutualism, commensalism, neutralism, e.g. Mucuna pruriens, Desmodium uncinatum, amensalism, competition, predations by predators for example, Rodolia cardinals, Neodusmetia sangwani, Philodromus cespitum and parasitism by parasities, e.g. Ichneumonid wasps, Braconid wasps (Acosta-Leal et al. 2011). Each plays their own significant role in control of the plant pathogens such as stimulation of host defense, consumption of pathogen biomass which ultimately led to death of pathogen, increase nutrition quality of plant and some creates an inability between the interactions of the population dynamics of plant species to the pathogen (Table 1) (Sundin et al. 2016).

- Two component system
1. A two component system mechanism can be implemented as it helps to inhibit the secondary growth of the pathogen thus acting as a great defence system, for instance Pseudomonas aurefaciens strain 30-84 is a biocontrol agent and has widely been used for all diseases related to wheat (Köhl et al. 2019).

2. In the process of the two systems, when a pathogen attacks on the roots it results in increasing the oozing process in roots which causes increase in growth of the bacteria in the infection region (Wiesel et al. 2014).

3. Therefore, in pseudomonas strain 30-84 the switching on of the PCA pathway occurs due to increase levels of the signal molecule, i.e. N-acyl-L-homoserine lactone (HSL), the activated PCA pathway increase in production of the PCA which inhibits the further growth of the bacteria (Nicot et al. 2011).

4. The strain 30-84 of Pseudomonas aurefaciens primarily does not decrease the severity of the infection but secondarily inhibit the growth of pathogen. Similarly, various fungal pathogens have been eliminated with help of the biocontrol agents such as actinoplane species can treat Pythium ultimum present in soil environment affecting table beet plant, treatment of Pythium aphanidermatum with help of the Pseudomonas aureofaciens strain 63-28 and inhibition of growth of the Rhizoctonia solani which affects tall fescue plant with treatment of Stenotrophomonas maltophilia C3 (Timms-Wilson et al. 2005).

5. The mode of action of bacterial species is by creating pores on the body of the pathogen, lysis of the fungal cell wall, degradation of the pathogens cell wall enzymes and completely inhibiting the metabolic pathway of the pathogens. Thus, resulting in complete elimination of the disease-causing agents (Kloepper et al. 1980).

- Siderophores-hey are compounds which are high in affinity towards iron-chelation; they are produced by bacteria and fungi. They play a great role in transport of iron across the cell membranes of the plants (Louws et al. 1999). Directly or indirectly these siderophores provides protection to the plants against various infectious pathogens for example, pyochelin protects tomato from Pythium. Some examples of biocontrol species of microbial agents with their interactions towards specific pathogens are mentioned in Table 2. 
Table 1 The detail of roles and the type of interactions

\begin{tabular}{|c|c|c|}
\hline Interaction & Role & References \\
\hline Mutualism & Stimulate host defense, improve nutrition in plants & Dodds and Rathjen (2010) \\
\hline Commensalism & $\begin{array}{l}\text { Presence of such relationship creates challenges for pathogens, absence of it led to decrease in } \\
\text { the severity of the infection }\end{array}$ & Eilenberg et al. (2001) \\
\hline Predators & $\begin{array}{l}\text { They consume pathogen biomass for their sustenance, e.g. protists, mesofauna and microar- } \\
\text { thropods }\end{array}$ & Jones and Dangl (2006) \\
\hline Neutralism & $\begin{array}{l}\text { It creates an inability between the interaction of the population dynamics of plant species to } \\
\text { the pathogen }\end{array}$ & Juroszek and von Tiedemann (2011) \\
\hline Competition & Led to decrease in growth of infectious microbes & Coakley et al. (1999) \\
\hline Parasites & Involves the use of hyperparasites that led to parasitize the plant pathogens & Scherm (2004) \\
\hline
\end{tabular}

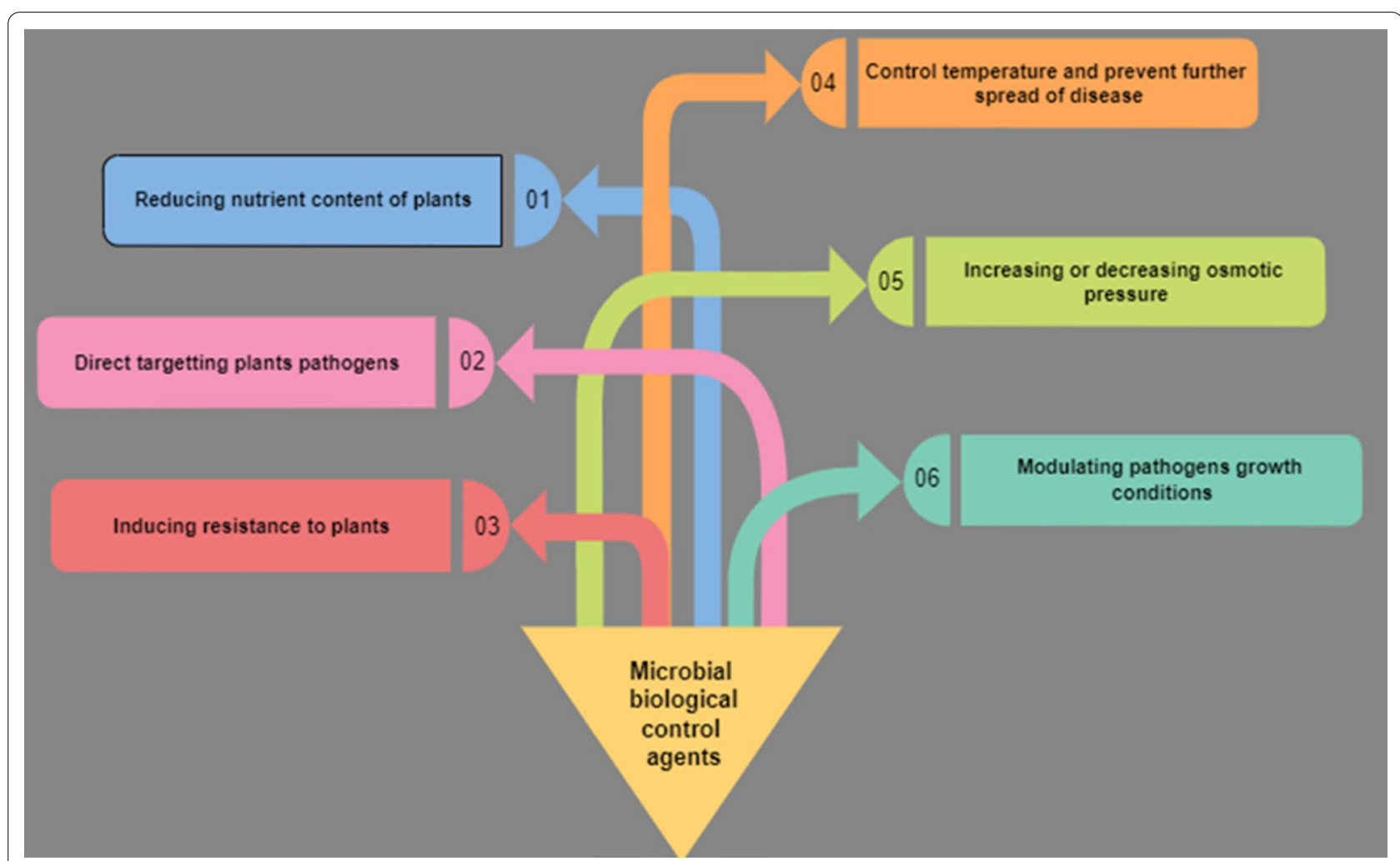

Fig. 3 Mode of action of microbial control agents

\section{Advantages of microbial bio control agents over chemical agents}

- Environmental friendly in nature and are effective even in small quantities.

- Decomposition of them is not an issue (Audenaert et al. 2002).

- They are target specific in nature. Thus, a specific microbe acts against a particular target or pathogen. Moreover, they do not affect other organism's even humans (Audenaert et al. 2002).
- Use of biological material is a cost-effective manner to control plant diseases in long term.

\section{Chemical control}

Similarly, like microbial agent's different chemicals are present in order to kill the infection-causing pathogens, these chemicals are classified as bactericides to kill bacteria, fungicides they destroy fungal spores causing infection and nematicides completely kill nematodes. Chemicals can be sprayed directly over plant surfaces 
Table 2 Examples of bio control agents and pathogens

\begin{tabular}{|c|c|c|c|c|c|}
\hline Biocontrol specie & Microbial agent & Pathogen & Interaction & Plant & References \\
\hline Bacteria & Comamonas acidovorans & Magnaporthe poae & $\begin{array}{l}\text { Bacteria biocontrol_fun- } \\
\text { gal pathogen }\end{array}$ & Kentucky bluegrass & Nicot et al. (2011) \\
\hline Fungi & Idriella bolleyi & Bipolaris sorokiniana & $\begin{array}{l}\text { Fungi biocontrol_fungal } \\
\text { pathogen }\end{array}$ & Barley & Timms-Wilson et al. (2005) \\
\hline Fungi & $\begin{array}{l}\text { Trichoderma harzianum } \\
\text { T-22 }\end{array}$ & $\begin{array}{l}\text { Pyrenophora triticis- } \\
\text { repentis }\end{array}$ & $\begin{array}{l}\text { Fungi biocontrol_fungal } \\
\text { pathogen }\end{array}$ & Wheat & $\begin{array}{l}\text { Timms-Wilson et al. } \\
\text { (2005), Kloepper et al. } \\
\text { (1980) }\end{array}$ \\
\hline Fungi & Pythium oligandrum & Verticillium dahlia & $\begin{array}{l}\text { Fungi biocontrol_fungal } \\
\text { pathogen }\end{array}$ & Pepper & Gaffney et al. (1994) \\
\hline Bacteria & Pseudomonas species & Fusarium oxysporum & $\begin{array}{l}\text { Bacteria biocontrol_-fun- } \\
\text { gal pathogen }\end{array}$ & Tomato & Louws et al. (1999) \\
\hline Fungi & $\begin{array}{l}\text { Trichoderma harzianum } \\
\text { BAFC } 742\end{array}$ & Sclerotinia sclerotiorum & $\begin{array}{l}\text { Fungi biocontrol_fungal } \\
\text { pathogen }\end{array}$ & Soybean & Kloepper et al. (1980) \\
\hline Bacteria & $\begin{array}{l}\text { Pseudomonas fluroescens } \\
\text { WCS358 }\end{array}$ & Fusarium oxysporum & $\begin{array}{l}\text { Bacteria biocontrol_fun- } \\
\text { gal pathogen }\end{array}$ & Radish & Nicot et al. (2011) \\
\hline
\end{tabular}

such as fruits, flowers and soil (Kliot et al. 2014). Each chemical control agent work on several mechanisms such as some of them inhibits the cell membrane ergosterol biosynthesis and prevents the development of the fungus (Table 3). Moreover, they supress the growth of the fire blight and frost forming bacteria on plant surface, break the DNA strands and results in loss of helical structure of the infectious organism present over plant surfaces. Some of them improves the water solubility in plants and effects the pathogens growth. Few nematicides are organophosphate in nature and thus inhibit the acetylcholine esterase synthesis which is required for the normal functioning of a plant (Nilsson 1995).

Although the chemicals are very effective in broad range to kill the microorganisms and control the plant disease from spreading, but there are some disadvantages of these chemicals. They affect the fertility of the soil, growth of the plants and the crops are consumed by humans and the chemicals indirectly affects them (Smith 1903).They induce immune toxicity in case of humans and thus resulting in suppression of the immune system. Consequently, give rise to autoimmune diseases. The

Table 3 Different groups and their uses are discussed as follows

\begin{tabular}{|c|c|c|c|}
\hline Chemical name & Group & Uses and mode of action & References \\
\hline Azoxystrobin & Fungicide & Effective against powdery and downy mildews fungus & Nilsson (1995) \\
\hline Acibenzolar-S-methyl & Fungicide & Used for Crops and vegetables & Nilsson (1995) \\
\hline Blight ban & Bactericide & Supress the growth of the fire blight and frost forming bacteria on plant surface & Pothier et al. (2011) \\
\hline Avermectin & Nematicide & Improves plants thermal stability and has greater water solubility & Bargabus et al. (2002) \\
\hline Carbendazim & Fungicide & $\begin{array}{l}\text { Controls mould, spot, mildew and scorch. It affects the biosynthesis of the DNA dur- } \\
\text { ing the process of the fungal cell division }\end{array}$ & Garnsey and Cambra (1991) \\
\hline Allyl isothicyanate & Nematicide & Broad spectrum in nature widely effective against numerous soil-borne pathogens & Bargabus et al. (2002) \\
\hline Cephalosporins & Bactericide & Inhibit cell wall synthesis of pathogens & Pothier et al. (2011) \\
\hline Difenoconazole & Fungicide & $\begin{array}{l}\text { Inhibits the cell membrane ergosterol biosynthesis and prevents the development } \\
\text { of the fungus }\end{array}$ & Nilsson (1995) \\
\hline Vancomycin & Bactericide & $\begin{array}{l}\text { It inhibits trans peptidase synthesis which further prevents elongation consequently } \\
\text { destroys the pathogen }\end{array}$ & Pothier et al. (2011) \\
\hline Cyanogen & Nematicide & Kills plant parasites & Kollerova et al. (2008) \\
\hline Myclozolin & Fungicide & Prevents the growth of the pathogens & Bargabus et al. (2002) \\
\hline Metronidazole & Bactericide & $\begin{array}{l}\text { Break the DNA strands and results in loss of helical structure of the infectious organ- } \\
\text { ism present over plant surface }\end{array}$ & Nilsson (1995) \\
\hline Diamidafos & Nematicide & $\begin{array}{l}\text { Organophosphate in nature and thus inhibits the acetylcholine esterase synthesis } \\
\text { which is required for the normal functioning of a plant }\end{array}$ & Kollerova et al. (2008) \\
\hline Telithromycin & Bactericide & Interferes with the protein synthesis of the bacteria and prevents its growth & Bargabus et al. (2002) \\
\hline
\end{tabular}


chemicals led to killing of some useful organisms such as chemicals effect the rate of the honeybee pollination, loss of birds and contaminating water streams led to death of aquatic animals (Cambra et al. 2000). Due to their disadvantages now research is more focused towards the introduction of the bio control agents. That will benefit the society economically and agricultural sector for the production of hybrid quality of products with better yield.

\section{Conclusions}

Different pathogens are responsible for causing plant diseases and due to them the major loss is faced by the agricultural industry. Earlier, the plant diseases were identified by visual examination the main symptoms such as curling of leaves and change of colour were observed. Moreover, traditional principles were adopted by the farmers in order to control the pathogen attack on the plants and to prevent any further spread of the disease. But as soon as technology came into existence different approaches were discovered to diagnose plant disease such as ELISA, FISH, western blotting and use of nucleic acids. They are widely due to less time consuming and effective results in regard to the type of the pathogen with proper identification. For prevention of further disease spread now the more focus is on microbial biological control agents (MBCAs) that supress the growth of the pathogen by inducing resistance to plants or by modulating the conditions required for the growth of a pathogen in the host body. The use of chemical pesticides and insecticides was abundant with their great positive effect rate but these chemicals result in causing environment and agricultural pollution so in order to preserve the environment various norms have been implemented by the government against such chemical pesticides. Consequently, now researchers are more focussed towards the development of the different microbial biological control agents in bulk against all plant species so as to control the plant infections with an alternative to chemical methods. Furthermore, the development of transgenic plants with transformed genes and use of variety of biosensors for the determination of plant diseases is the current focus in the forthcoming times. In addition, use of nanoparticles for the development of biosensors as they can improve the working capacity of a biosensor. The development of more such biosensors is under process in order to cover wide range of plant disease detection.

\footnotetext{
Abbreviations

BCA: Biological control agents; CymMV: Cymbidium mosaic virus; DTBIA: Direct tissue blot immunoassay; ELISA: Enzyme-linked immunosorbent assay; FISH: Fluorescence in situ hybridization; FAO: Food and agricultural organization; ITS: Internal transcribed spacers; MBCAs: Microbial bio control agents; ORSV:
}

Odontoglossum ringspot virus; PCR: Polymerase chain reaction; PPV: Plumpox virus; RFLP: Restriction fragment length polymorphism.

\section{Acknowledgements}

Not applicable.

\section{Authors' contributions}

SGS reviewed and interpreted the Plant diseases and their management. LK collected and analysed the various approaches of plant disease management and was a major contributor in writing the manuscript. Both authors read and approved the final manuscript.

\section{Funding}

No financial disclosures.

Availability of data and materials

Contact authors.

\section{Declarations}

Ethics approval and consent to participate Not applicable.

\section{Consent for publication}

Not applicable.

\section{Competing interests}

The authors declare that they have no competing interests.

\section{Author details}

${ }^{1}$ Department of Biotechnology, School of Biosciences and Bioengineering, Lovely Professional University, Phagwara, Punjab, India. ${ }^{2}$ Department of Microbiology, College of Basic Sciences and Humanities, Punjab Agricultural University, Ludhiana, Punjab, India.

Received: 16 June 2021 Accepted: 27 September 2021

Published online: 09 October 2021

\section{References}

Acosta-Leal R, Duffy S, Xiong Z, Hammond RW, Elena SF (2011) Advances in plant virus evolution: translating evolutionary insights into better disease management. Phytopathology 101(10):1136-1148

Alkhalaf MA, Kumari SG, Kasem AH, Makkouk K (2009) Use of the two faces of nitrocellulose membrane in tissue blot immunoassay for the detection of Bean yellow mosaic virus and the Possibility of its mechanically transmitted from the printed membrane to the host plant. Arab J Plant Protect 27:91-94

Aslam S, Tahir A, Aslam MF, Alam MW, Shedayi AA, Sadia S (2017) Recent advances in molecular techniques for the identification of phytopathogenic fungi-a mini review. J Plant Interact 12(1):493-504

Audenaert K, Pattery T, Cornelis P, Hofte M (2002) Induction of systemic resistance to Botrytis cinerea in tomato by Pseudomonas aeruginosa 7NSK2: role of salicylic acid, pyochelin and pyocyanin. Mol PlantMicrobe Interact 15:1147-1156

Bargabus RL, Zidack NK, Sherwood JW, Jacobsen BJ (2002) Characterization of systemic resistance in sugar beet elicited by a non-pathogenic, phyllosphere colonizing Bacillus mycoides, biological control agent. Physiol Mol Plant Pathol 61:289-298

Barnes CW, Szabo LJ (2007) Detection and identification of four common rust pathogens of cereals and grasses using real-time polymerase chain reaction. Phytopathology 97(6):717-727

Bashan Y, Holguin G (1998) Proposal for the division of plant growthpromoting rhizobacteria into two classifications: biocontrol-PGPB (plant growth-promoting bacteria) and PGPB. Soil Biol Biochem 30:1225-1228

Beale RE, Pitt D (1995) The antifungal properties of Minimedusa polyspora. Mycol Res 99:337-342 
Belet Chane T, Boyraz N (2019) Biotechnological tools for detection, identification and management of plant diseases. Afr J Biotechnol 18:798-805

Bonaterra A, Cabrefiga J, Camps J, Montesinos E (2007) Increasing survival and efficacy of a biocontrol agent of fire blight of rosaceous plants by means of osmoadaptation. FEMS Microbiol Ecol 61:185-195

Bürling K, Hunsche M, Noga G (2011) Use of blue-green and chlorophyll fluorescence measurements for differentiation between nitrogen deficiency and pathogen infection in winter wheat. J Plant Physiol 168:1641-1645

Cambra M, Gorris MT, Román MP, Terrada E, Garnsey SM, Camarasa E, Olmos A, Colomer M (2000) Routine detection of citrus tristeza virus by direct immunoprinting-ELISA method using specific monoclonal and recombinant antibodies, pp 38-40

Chitarra LG, van den Bulk RW (2003) The application of flow cytometry and fluorescent probe technology for detection and assessment of viability of plant pathogenic bacteria. Eur J Plant Pathol 109:407-417

Coakley SM, Scherm H, Chakraborty S (1999) Climate change and plant disease management. Annu Rev Phytopathol 37:399-426

Dodds PN, Rathjen JP (2010) Plant immunity: towards an integrated view of plant-pathogen interactions. Nat Rev Genet 11:539-548

Dun-chun HE, Lian-hui XIE (2016) Problems, challenges and future of plant disease management: from an ecological point of view. J Integr Agric 15(4):705-710

Eilenberg J, Hajek A, Lomer C (2001) Suggestions for unifying the terminology in biological control. Biocontrol 46:387-400

Fang Y, Ramasamy RP (2015) Current and prospective methods for plant disease detection. MDPI Biosens 5:537-549

Gaffney TD, Lam ST, Ligon J, Gates K, Frazelle A, Di Maio J, Hill S, Goodwin S, Torkezitz N, Allshouse AM, Kempf H-J, Becker JO (1994) Global regulation of expression of antifungal factors by a Pseudomonas fluorescens biological control strain. Mol Plant Microbe Interact 7:455-463

Gaillet S, Rouanet JM (2015) Silver nanoparticles: their potential toxic effects after oral exposure and underlying mechanisms-a review. Food Chem Toxicol 77:58-63

Garnsey SM, Cambra M (1991) Enzyme-linked immunosorbent assay (ELISA) for citrus pathogens. In: Roistacher CN (ed) GraftTransmissible diseases of citrus. Handbook for detection and diagnosis. Food and Agriculture Organization of the United Nations, Rome, pp 193-216

Garnsey SM, Permar TA, Cambra M, Henderson CT (1993) Direct tissue blot immunoassay (DTBIA) for detection of citrus tristeza virus (CTV), vol 12, no 12, pp 39-44

Garrett KA, Jumpponen A, Gomez Montano L (2010) Emerging plant diseases: what are our best strategies for management? In: Kleinman DL, Delborne J, Cloud-Hansen KA, Handelsman J (eds) Controversies in science \& technology volume 3 : from evolution to energy. Mary Ann Liebert Inc, New Rochelle, pp 152-160

Gullino ML, Kuijpers LAM (1994) Social and political implications of managing plant diseases with restricted fungicides in Europe. Annu Rev Phytopathol 32:559-575

Hijri M (2009) The use of fluorescent in situ hybridisation in plant fungal identification and genotyping, pp 4-6

Jones RAC (2009) Plant virus emergence and evolution: origins, new encounter scenarios, factors driving emergence, effects of changing world conditions, and prospects for control. Virus Res 141:113-130

Jones JDG, Dangl JL (2006) The plant immune system. Nature 444:323-329

Juroszek P, Von Tiedemann A (2011) Potential strategies and future requirements for plant disease management under a changing climate. Plant Pathol 60(1):100-112

Kliot A, Kontsedalov S, Lebedev G, Brumin M, Cathrin PB, Marubayashi JM, Skaljac M, Belausov E, Czosnek H, Ghanim M (2014) Fluorescence in situ hybridizations (FISH) for the localization of viruses and endosymbiotic bacteria in plant and insect tissues. J Vis Exp

Kloepper JW, Leong J, Teintze M, Schroth MN (1980) Enhanced plant growth by siderophores produced by plant growth promoting rhizobacteria. Nature 286:885-886

Koczula KM, Gallotta A (2016) Lateral flow assays. Essays Biochem 60(1):111-120

Köhl J, Kolnaar R, Ravensberg WJ (2019) Mode of action of microbial biological control agents against plant diseases: relevance beyond efficacy. Front Plant Sci 10:845
Kollerova E, Glasa M, Subr ZW (2008) Western blotting analysis of the plum pox virus capsid protein. J Plant Pathol 21-23

Lievens B, Brouwer M, Vanachter ACRC, Cammue BPA, Thomma BPHJ (2006) Real-time PCR for detection and quantification of fungal and oomycete tomato pathogens in plant and soil samples. Plant Sci 171:155-165

Lopez MM, Bertolini E, Olmos A, Caruso P, Corris MT, Llop P, Renyalver R, Cambra M (2003) Innovative tools for detection of plant pathogenic viruses and bacteria. Int Microbiol 6:233-241

Louws FJ, Rademaker JLW, Brujin FJ (1999) The three Ds of PCR-based genomic analysis of phytobacteria: diversity, detection, and disease diagnosis. Annu Rev Phytopathol 37:81-125

Lugtenberg B, Leveau J (2007) Biocontrol of plant pathogens: principles, promises, and pitfalls. In: Pinton R, Varanini Z, Nannipieri P (eds) The rhizosphere: biochemistry and organic substances at the soil-plant interface. CRC Press, Boca Raton, pp 267-293

Martinelli F, Scalenghe R, Davino S, Panno S, Scuderi G, Ruisi P, Villa P, Stroppiana D, Boschetti M, Goulart LR, Davis CE, Dandekar AM (2014) Advanced methods of plant disease detection-a review, INRA Science and impact. Agron Sustain Dev 35:5-20

Mehta A, Rosato YB (2001) Differentially expressed proteins in the interaction of Xanthomonas axonopodis pv. citri with leaf extract of the host plant. Proteomics 1:1111-1118

Nicot P, Bardin M, Alabouvette C, Köhl J, Ruocco M (2011) Potential of biological control based on published research. Protection against plant pathogens of selected crops, pp 2-10

Nilsson H-E (1995) Remote sensing and image analysis in plant pathology. Can J Plant Pathol 17:154-166

Nutter FW Jr, Schultz PM (1995) Improving the accuracy and precision of disease assessments: selection of methods and use of computeraided training programs. Can J Plant Pathol 17:174-184

Nygren K, Dubey M, Zapparata A, Iqbal M, Tzelepis GD, Durling MB et al (2018) The mycoparasitic fungus Clonostachys rosea responds with both common and specific gene expression during interspecific interactions with fungal prey. Evol Appl 11:931-949

Pothier JF, Pagani MC, Pelludat C, Ritchie DF, Duffy B (2011) A duplex-PCR method for species and pathovar level identification and detection of the quarantine plant pathogen Xanthomonas arboricola pv. pruni. J Microbiol Methods 86:16-24

Scherm H (2004) Climate change: can we predict the impacts on plant pathology and pest management? Can J Phytopathol 26:267-273

Shanti ML, Shenoy VV, Lalitha Devi G, Mohan Kumar V, Premalatha P, Naveen Kumar G, Shashidhar HE, Zehr UB, Freeman WH (2010) Marker-assisted breeding for resistance to bacterial leaf blight in popular cultivar and parental lines of hybrid rice. J Plant Pathol 92(2):495-501

Singh Y, Singh J, Pandey AK (2013) Molecular markers in diagnosis and management of fungal pathogens: a Review. Int J Adv Biotechnol Res 4(2):180-188

Smith $E$ (1903) Observations on a hitherto unreported bacterial disease, the cause of which enters the plant through ordinary stomata. Science 17:456-457

Spadaro D, Gullino ML (2004) State of the art and future prospects of the biological control of postharvest fruit diseases. Int J Food Microbiol 91:185-194

Spadaro D, Gullino ML (2005) Improving the efficacy of biocontrol agents against soilborne pathogens. Crop Prot 24:601-613

Sundin GW, Castiblanco LF, Yuan X, Zeng Q, Yang CH (2016) Bacterial disease management: challenges, experience, innovation and future prospects, challenges in bacterial molecular plant pathology. Mol Plant Pathol 17(9):1506-1518

Timms-Wilson TM, Kilshaw K, Bailey MJ (2005) Risk assessment for engineered bacteria used in biocontrol of fungal disease in agricultural crops. Plant Soil 266:57-67

Torres AM (2010) Application of molecular markers for breeding disease resistant varieties in crop plants. In: Molecular techniques in crop improvement. Springer, Dordrech, pp 185-205

Weller DM (2007) Pseudomonas biocontrol agents of soil borne pathogens: Looking back over 30 years. Phytopathology 97:250-256

Whipps JM (2001) Microbial interactions and biocontrol in the rhizosphere. $J$ Exp Bot 52(1):487-511 
Wiesel L, Newton AC, Elliott I, Booty D, Gilroy EM, Birch PRJ et al (2014) Molecular effects of resistance elicitors from biological origin and their potential for crop protection. Front Plant Sci 5:655

Zhang H, Zheng X, Fu C, Xi Y (2005) Postharvest biological control of gray mold rots of pear with Cryptococcus laurentii. Postharvest Biol Technol 35:79-86

\section{Publisher's Note}

Springer Nature remains neutral with regard to jurisdictional claims in published maps and institutional affiliations.

\section{Submit your manuscript to a SpringerOpen ${ }^{\odot}$ journal and benefit from:}

- Convenient online submission

- Rigorous peer review

- Open access: articles freely available online

- High visibility within the field

- Retaining the copyright to your article

Submit your next manuscript at $\boldsymbol{\nabla}$ springeropen.com 